\title{
Fuel, Feed and the Corporate Restructuring of the Food Regime
}

\author{
JOSEPH BAINES \\ York University, Department of Political Science, 4700 Keele Street, Toronto, Ontario, Canada. \\ Email: josephbaines714@gmail.com \\ This is an Author's Accepted Manuscript of an article published in The Journal of \\ Peasant Studies, November, 2014, [copyright Taylor \& Francis], available online \\ at: \\ http://www.tandfonline.com/doi/full/10.1080/03066150.2014.970534\#.VMYB4_6s \\ Uy8
}

\begin{abstract}
The agrofuel boom has brought about some of the most significant transformations in the world food system in recent decades. A rich and diverse body of agrarian political economy research has emerged that elucidates the conflicts and redistributional shifts engendered by these transformations. However, less attention has been given to differences within agrifood capital. This paper contributes to the existing literature on agrofuels, by showing how one cluster of agri-food corporations and farmers within the US has benefited from soaring ethanol production at the expense of another cluster. More specifically, I delineate and chart the pecuniary trajectories of two corporate-led coalitions that have vied over the course taken by the US ethanol sector: the 'Agro-Trader nexus' and the 'Animal Processor nexus'. My main finding is that the US ethanol boom has been a vector of redistribution: increasing the earnings of the Agro-Trader nexus and corn growers while reducing the earnings of the Animal Processor nexus and livestock farmers. This finding points to the limits and contradictions of agrofuels capitalism and the acute tensions that exist at the heart of the corporate food regime.
\end{abstract}

Keywords: agrofuels; food regimes; redistribution; Agro-Trader nexus; industrial livestock

\section{Introduction}

The surge in the production of agrofuels in general, and US ethanol in particular, represents one of the most significant transformations in the world food system in recent decades. After a series of government initiatives to support the ethanol sector from the early 2000s onward, the diversion of corn into the US's agrofuel feedstocks increased dramatically. In 2001, US ethanol production accounted for $34 \%$ of the global production of agrofuels. Ten years later this figure rose to $48 \%$ (US EIA 2013). The American ethanol sector is now so large that it consumes around two-fifths of the corn produced in the US. The channelling of grain into fuel production has, according to many analyses, been a chief contributor to ris- 
ing food prices since the beginning of the twenty-first century. A leaked World Bank internal report estimates that $70-75 \%$ of the food price rises between 2002 and 2008 were caused by the absorption of grain into burgeoning global agrofuel feedstocks; and a study by researchers at the New England Complex Systems Institute contends that the US ethanol sector alone was the preponderant long-term driver of food price inflation between 2004 and 2011 (Mitchell 2008, Lagi et al. 2011). These food price hikes have had grave impacts. According to one estimate, the 'real' price paid by the world's landless poor for major calorie staples has doubled since 2004 (Wright 2014).

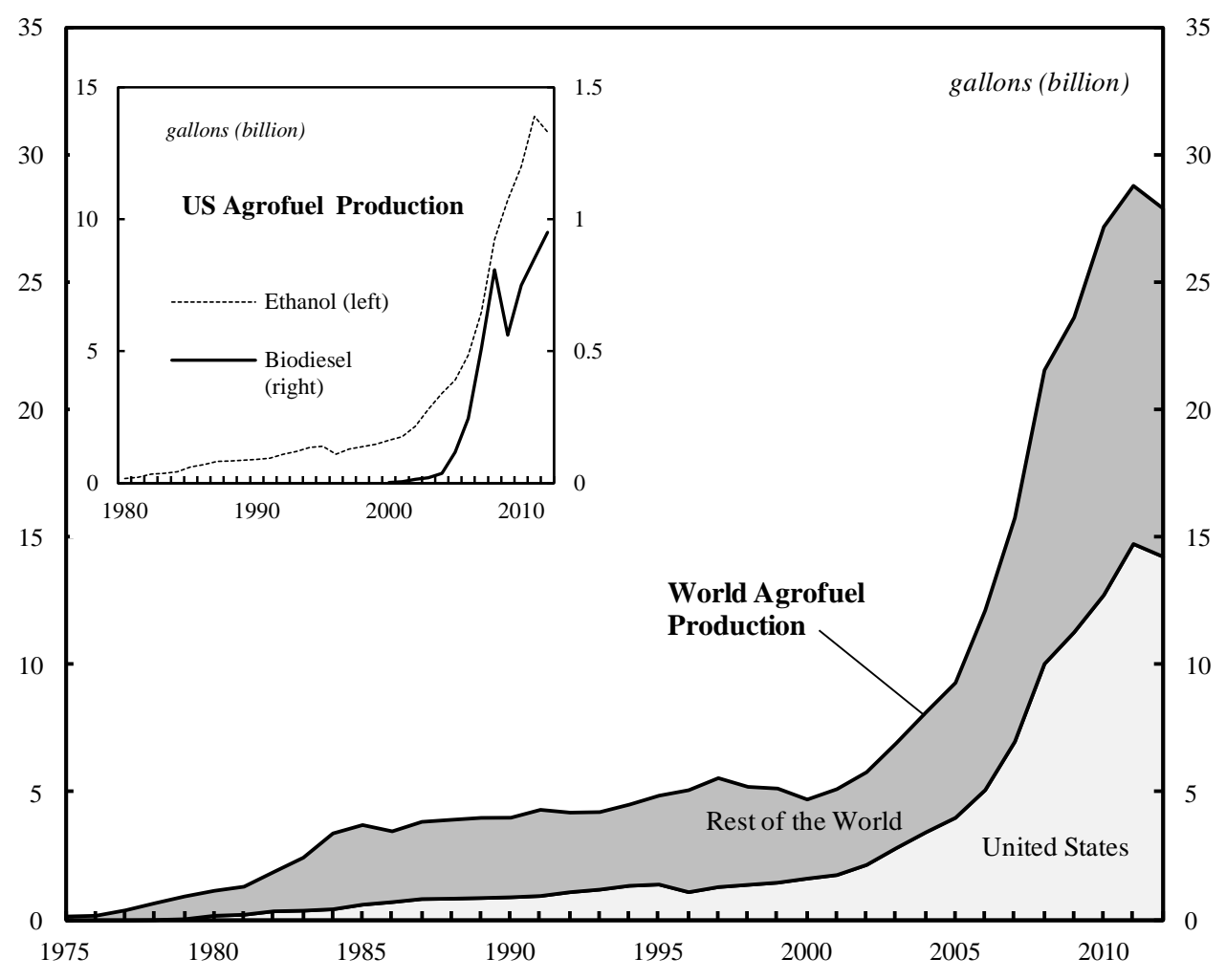

Figure 1: Agrofuel Production in the US and the Rest of the World

Source: 1975-2010 data from the Earth Policy Institute (2014). 2011-12 data from Worldwatch Institute (2014)

The wrenching changes brought about by soaring ethanol and biodiesel production (see Figure 1) have prompted some scholars to ask whether the methods of agrarian political economy are adequate to the task of analyzing the agrofuel boom. In an important overview of 'agrofuels capitalism', Ben White and Anirban Dasgupta address this issue directly. They suggest that the existing tools of analysis offered by agrarian political economy can be used to explain the contemporary agrofuel boom, just as these tools help to explain expansions in large-scale, monocrop agriculture in the past. A political economy approach, they argue, focuses our attention on 'the social relations of production and reproduction 
and the structures of accumulation or (dis)accumulation' generated by agrarian change, and the 'accompanying processes of social differentiation and class formation' $(2010,600)$. This focus, they contend, is encapsulated by Henry Bernstein's catechism: 'who owns what? who does what? who gets what? what do they with it?' In the case of agrofuels, White and Dasgupta suggest that Bernstein's formulation can be distilled into three questions: Where does the land for the growing of agrofuel feedstocks come from? How is agrofuel production organized? And for whose benefit? In seeking to answer these questions, White and Dasgupta contend that we will establish 'the actors involved and the added value in different points in the agrofuels commodity chain, the power positions and relations of the various actors, and the role of external agencies, including government' $(2010,605)$.

A significant amount of agrarian political economy research has advanced the project of identifying the various actors and interests involved in the agrofuel boom (Borras et al. 2010). These contributions offer rich insights in regard to the conflictual and redistributional dynamics brought about by soaring ethanol and biodiesel production, at a variety of social scales. The broadest and most wide-ranging appraisal of the agrofuel boom is perhaps offered by Philip McMichael. In his macroscopic analysis, McMichael (2009a, 2009b, 2010, 2012) combines a world-historical conception of capital accumulation with important observations garnered from case-study investigations of the agrofuel boom. Some scholars offer detailed examinations of how the broad processes of capital accumulation, outlined so well by McMichael, play out in terms of regressive redistribution within regions (Dauvergne and Neville 2009, Richardson 2010, 2012), while others focus on the redistributional shifts, land-use changes and struggles around agrofuel development at the national level (Carolan 2009, Novo et al. 2010, Wilkinson and Herrera 2010, Holleman 2012, MintzHabib 2013). Crucially, there are also a number of fine-grained analyses of the differentiated ways in which agrofuels development impact, and are mediated by, local agrarian class structures and ethnic divisions (Gillon 2010, Vermeulen and Cotula 2010, Borras et al. 2011, McCarthy et al. 2011, Bain et al. 2012, Bain and Selfa 2013, Montefrio and Sonnefield 2013). And finally, some scholars have extended agrarian political economy's focus on conflict and social differentiation to the domain of gender relations, by examining the variegated effects that expanding agrofuels production have had on men and women (Rometsch 2012, Julia and White 2013).

These contributions affirm the importance of the agrarian political economy framework to our understanding of the agrofuel boom. Not only does this body of literature successfully distinguish the interests and roles of various rural constituencies in regard to ethanol and biodiesel production, it also offers significant insights in regard to the ways in which corporations work with government to institutionalize agrofuels capitalism. However, hitherto this point, less attention has been given to differences within agri-food capital. The analysis offered in this paper seeks to contribute to existing research by extending the agrarian political economy project of social disaggregation more explicitly to the domain of agribusiness. In particular, I suggest that through charting shifts in accumulation and earnings within US agribusiness and agriculture we can make better sense of the struggles between corporate-led coalitions over the future trajectory of the US ethanol sector. My qualitative cum quantitative investigation of the uneven distributional consequences of the ethanol boom adds important details to the analysis of agrofuels development because it helps the researcher cut across the agribusiness/agriculture divide to show how one cluster of farmers and agri-food corporations appears to be benefiting at the expense of another. By specifying the winners and losers of the agrofuel boom in this manner, the paper sheds light on the 
acute tensions that exist at the heart of the corporate food regime and the limits and contradictions of agrofuels capitalism at large.

The investigation focuses on the US ethanol sector as it is the global epicenter of the agrofuel boom. I identify and analyze two rival constellations of corporate power within the US food system. The first is the Agro-Trader nexus. The core of this nexus comprises one of the world's largest grain processors along with a triumvirate of agricultural input firms. The second is the Animal Processor nexus. This constellation comprises the major firms that oversee the conversion of animal life into meat products. The feed grain sector lies at the interstices of the Agro-Trader nexus and the Animal Processor nexus and, as a result, it has become the site of intense redistributional conflict between the two business configurations. As I argue, the corn-ethanol boom has been a manifestation of this struggle. More specifically, soaring corn-ethanol production has shifted the balance of feed grain prices in a way that benefits the Agro-Trader nexus and corn growers to the detriment of the Animal Processor nexus and livestock farmers. Concomitantly, while the Agro-Trader nexus and corn growers have championed government support for the corn-ethanol sector, the Animal Processor nexus and most livestock farmers have opposed it. Thus, changes in the relative price of feed grain on the one hand, and changes in the relative accumulation of the Agro-Trader nexus and the Animal Processor nexus on the other, are two sides of the same process of redistributional restructuring and social differentiation in US agribusiness and agriculture.

The paper comprises three sections. The first section takes Philip McMichael's account of agrofuels as its point of departure. As I have already suggested, the importance of McMichael's work lies in its situating of soaring ethanol and biodiesel production in relation to the world-historical dynamics of capital accumulation. In this respect, his analysis offers an important analytical map that helps orient those researchers conducting investigations on agrofuels at regional, national and local levels. However, by virtue of the wide-ranging scale at which he navigates the changing global food-fuel landscape and by virtue of his aggregative outlook on capital accumulation, McMichael tends to underspecify the redistributional conflicts within agribusiness over agrofuels production. This under-specification is typified by his assertion that agrofuels represent a 'portal' for the increased profitability of 'capital in general'. The second section seeks to add to McMichael's account by outlining the singularly important role played by Archer Daniels Midland (ADM), rather than simply the structural imperatives of capital in general, in the development of the US ethanol sector from the 1970s to the 1990s. The third section investigates how the bifurcation of US agriculture into commoditycrop production and animal-meat production, and the concomitant division of agribusiness between the Agro-Trader nexus and the Animal Processor nexus, plays into the distributional dynamics of soaring ethanol production in the 2000s. As I show, while the US ethanol boom may have increased the profitability of capital in general, it has also been a vector of redistribution: increasing the earnings of the Agro-Trader nexus and corn growers while reducing the earnings of the Animal Processor nexus and livestock farmers. In the conclusion, I indicate how these domestic distributional struggles reverberate across the entire global political economy of food and I point to directions for future research. 


\section{The food regime analysis of agrofuels}

McMichael's analysis of the agrofuel boom is primarily anchored in the food regime framework. The framework was propounded by Harriet Friedmann (1987) and it received further substantiation two years later in a landmark article that she authored with McMichael. In this article, Friedmann and McMichael (1989) identify stabilized relations in the production, trade and consumption of food, from the period of high colonialism onwards. These stabilized relations emerge out of particular balances of social forces, within and between imperial metropoles, colonies and settler-states, and then later within and between advanced capitalist countries and the newly decolonized nations of the Third World. The approach combines a world-systems theory perspective on geographical specialization with a method of periodizing capitalism derived from the French Regulation School. Added to this theoretical synthesis is a focus on the evolution of various agri-food complexes that connect farmers to consumers through various webs of supply chains (Friedmann and McMichael 1989, McMichael 2009a).

Friedmann and McMichael originally identified two food regimes. The first food regime was centered on British hegemony in the late nineteenth and early twentieth centuries. It combined the sequestering of exotic goods from tropical colonies with the importation of basic grains and livestock from the more temperate settler states, the most important one of which was the US. The cheap prices ensured by this imperial arrangement enabled rapid industrialization in the metropolitan heartlands of capitalism. However, the first food regime ran into social and ecological limits. Highly fertile ecosystems became exhausted by soil-mining. Moreover, family farmers were, by the 1920s and 1930s, becoming increasingly exposed to the exigencies of a depressed world market. The deleterious effects of this food regime were perhaps most starkly exposed by the overlapping social and ecological catastrophes of the Great Depression and Dustbowl. Vast swathes of rural America were denuded by drought and hundreds of thousands of farmers were stripped of all means of earning a decent income. The second regime was centered on US hegemony and it emerged out of the social and environmental dislocation of the 1930s. In this context, family farmers within the US resolved to build a powerful constellation of lobbying organizations to represent their interests. The resulting 'farm bloc' became an important force in US agricultural policy for over three decades. Indeed, having rallied behind the Roosevelt administration's New Deal in the 1930s, the farm bloc had won, and then defended, a suite of government measures - including price supports, production controls, tariffs and 'food aid' that buffered agricultural producers from market instability. These government protections contributed to a provisional resolution of the crisis that precipitated the first food regime's collapse (Friedmann and McMichael 1989, Friedmann 2005).

Drawing on the analysis of agro-industrial development offered by David Goodman et al. (1987), Friedmann and McMichael identify two long-running processes that would eventually undermine the second food regime. Firstly, agri-food capitals intensified their appropriation of aspects of the agricultural process through the transformation of farming into discrete elements of business control. For example, by the 1940 s, the farm-reared horse was almost completely replaced by the motorized tractor 
for tilling; and the recycling of organic waste, such as manure, into farm soil was marginalized by the wholesale introduction of chemical fertilizers. Secondly, agri-food capitals intensified their substitution of traditional foods produced in the tropics, such as cane sugar and peanut oil, with derivatives of commodities that could be produced in more temperate climes, such as high fructose corn syrup (HFCS) and soybean oil. Friedmann and McMichael convincingly argue that these processes of appropriation and substitution enabled agri-food capitals to integrate the world food system by breaking agriculture into specialized sectors connected through supply chains that cut across national boundaries. This dynamic was evidenced in the emergence of the transnational 'durable food complex' and the 'livestock-feed complex'. With the emergence of these complexes, agricultural production moved away from closed-loop processes of energy and nutrient recycling controlled by farmers, toward a linear process, comprising commodified inputs and outputs that were bought from, and sold to, increasingly powerful agribusiness firms (Friedmann and McMichael 1989, Weis 2007). As agricultural production became more linear, farming became more specialized, more capitalintensive and thus less favorable to small family farm operations. These trends, in turn, contributed to a decline in the farmer population and the fragmentation of farmer interests along the lines of commodity specialization. Thus, the farm bloc was critically undermined, as broad-based agricultural lobbies that represented the interests of small farmers were superseded by commodity-specific interest groups that were principally commandeered by agri-food corporations. As Friedmann and McMichael (1989) argue, the decline of the US farm bloc, along with the intensification of international trade rivalries, contributed significantly to the unravelling of the second food regime in the 1970s and 1980s.

Given the food regime approach's proven capacity to clarify and orient analysis of the complexities of the political economy of food, it is no surprise that at the beginning of his most extensive exploration of agrofuels, McMichael (2009b) uses the original framework as his guide. Having outlined the colonial and the US-centered food regimes, McMichael suggests that the agrofuels sector is developing within a 'corporate food regime' and is taking shape around a 'food/fuel complex': a network of recombinant corporate arrangements that combine the appropriation of agricultural processes by major seed companies, with the substitution of food for fuel, through alliances of grain, meat and energy companies. For McMichael, these recombinant corporate arrangements represent a profound epistemological assault whereby capitalist value relations are superimposed onto extant systems of provisioning.

To cite him directly, "the agrofuels "gold rush" reveals the one-dimensionality of value relations as embodied in capitalism and its structures of thought' (2010, 622). Given his focus on 'structures of thought', McMichael enjoins agrarian political economists to relay the 'ecologically relevant discourses' that counter the 'value calculus through which capital rules the world' (2010, 622-6). This project of emphasizing the endurance of suppressed knowledges within the world food system has a lot to recommend it. However, if we overlook the contestation between agri-food capitals, there is a danger that we may ascribe an unduly uniform metanarrative to capital accumulation itself. The tendency to underspecify the contrasting interests of agri-food capital can be adduced from McMichael's statement that the agrofuel boom: 
'follows a typical capital accumulation script - that is, attempting to overcome barriers to profitability by extending the realm of value creation, even as this in tensifies capitalism's contradictions... The 'agrofuels project' is central to this attempt to maintain profit, and to legitimize the state/capital nexus' (2009b, 825-6).

The assertion that the 'agrofuels project' legitimizes a 'state/capital nexus' as a whole is instructive at a macroscopic level of analysis. Nonetheless, we should also be attentive to the fact that different corporations seek to justify their competing attempts at reorganizing the contemporary food regime with recourse to different, and oftentimes rival, claims to legitimacy. The tendency to de-emphasize the role of intra-capitalist conflict over agrofuels is further evidenced in his assertion that 'biofuels constitute another portal through which capital in general can profit from agriculture' $(2010,613$, my emphasis). The issue here is that although 'capital in general' is a potent category from a systemic perspective, it does not tell us much about the redistributional struggles that are occurring within agribusiness over agrofuels production. Thus, even when McMichael does refer to individual corporations in his analysis of agrofuels (2009c, 290-91), there is a danger that the reader may mistake these corporations as being mere standard-bearers of monolithic capitalist interests.

This paper seeks to develop the food regime account of agrofuels through a more concerted examination of the distributional dynamics of surging corn-ethanol production. Moving from McMichael's panoramic conception of 'capital in general' to a detailed investigation of different groups of agri-food capital, I endeavor to identify the winners and losers of the ethanol boom, within both US agribusiness and agriculture. In so doing, I address a number of key questions that are opened by the food regime approach, and by agrarian political economy, more generally: How has the decomposition of agricultural production into discrete phases appropriated by agribusiness impacted social differentiation within rural America? How has the rendering of agricultural products into substitutable commodities used in both food and energy sectors impacted processes of (dis)accumulation within agri-food capital? And finally, what tensions do these processes of social differentiation and (dis)accumulation bring to bear? With these questions in mind, the next section seeks to add to McMichael's account by outlining the instrumental role that the substitutionist accumulation strategies of just one company - ADM - have played in the development of the food/fuel complex in the US. And the following section describes how this company has formed connections with corporations that have appropriated control over key aspects of commodity-crop production, to form an axis of corporate power that helped push the food/fuel complex to the forefront of the agrarian political economy of the US at the beginning of the twenty-first century. Finally, I show how major meat packing companies have sought to resist the ascendance of the food/fuel complex and I outline the distributional consequences of this struggle. 


\section{Archer Daniels Midland and the political institutionalization of the US food/fuel complex}

The conversion of plant biomass into transportation fuel has a long history (see Carolan 2009). But the food/fuel complex that exists in the US today emerged in the 1970s, following three decades in which ethanol was completely marginalized as a source of energy. The renaissance of the ethanol sector was made possible by extensive government subsidies and the assiduous lobbying efforts of one firm: ADM. The company's successful championing of the food/fuel complex took place against the backdrop of two key developments. Firstly, as the main chart in Figure 2 shows, gasoline prices were soaring as a result of the transition of Middle East oil production from a 'freeflow' regime to a 'limited flow' regime (Nitzan and Bichler 2002). Secondly, just as controls over Middle East oil production were being tightened, controls over US grain production were being loosened. This general loosening of government regulations over agricultural production was in large part a result of the fracturing of the farm bloc and the coeval rise in the power of agribusiness (Feedstuffs Magazine 1968, Friedmann and McMichael 1989). The passing of the 1973 Farm Bill was a key turning point as it initiated the dismantling of the comprehensive system of agricultural price supports that had existed since the New Deal era. Set-aside controls were suspended, public grain reserves were emptied, prices were allowed to fall below the cost of production, and farmers' incomes were now supported by direct payments from government (Winders 2009, Lehrer 2010). No matter how much market prices fell, farmers could keep on producing more, safe in the knowledge that they would receive direct payments that would make up the difference between the prices they got for their crop and the 'target prices' set by the US Department of Agriculture (USDA). As the left insert of Figure 2 shows, the amount of US land devoted to corn production subsequently increased after a four decade decline. Wheat production also rebounded.

The soaring gasoline prices of the late 1970s conferred more credibility upon those who supported greater energy independence through the expanded use of US-produced alternatives to petroleum; and the general rise in corn production increased the feasibility of corn-ethanol being one of these alternatives. The grain processing giant, ADM, seized the opportunity and relentlessly championed ethanol as a petroleum substitute. $\mathrm{ADM}$ at this point was the pre-eminent force in the durable food complex. It had long been the front-runner in developing myriad soy derivatives (Southwestern Miller Magazine 1972). Moreover, it dominated HFCS production, with its corn wet mills churning out one-third of the national output of the sweetener (ERS 1993, 22). However, ADM's HFCS operations were buffeted by seasonal cycles in consumption patterns. During the summer soft drink sales soar. But in the winter such beverages are not so popular. ADM figured that if the right government supports were in place, the very same corn mills that turned out HFCS to sweeten the huge quantities of Coke and Pepsi drunk by thirsty American consumers in the summer months, could in the slow-selling winter months, produce ethanol to be guzzled by American automobiles. These seasonal switches of output in what ADM called its 'sweetener/alcohol complex' would ensure that the company's corn milling plants ran close to capacity, thereby boosting sales and minimizing production costs (Milling \& Baking News 1982, 32). It was with- 
in the womb of ADM's sweetener/alcohol complex that the broader food/fuel complex first developed.

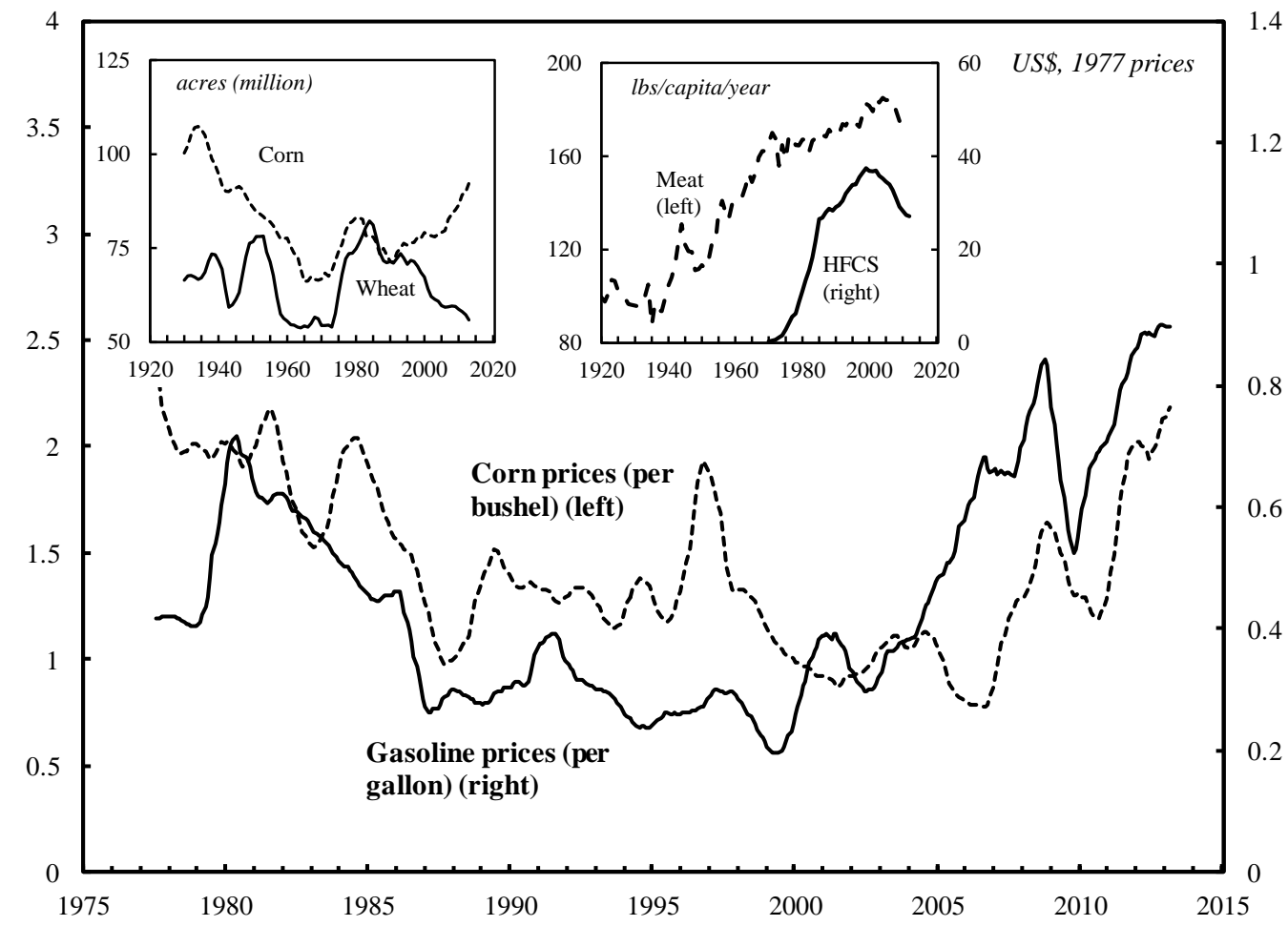

Figure 2: Transformations in the Political Economy of Corn

Note: Corn and gasoline prices presented as 1-year moving averages and deflated by the US chaintype price index. Acreage data presented as 5-year moving averages.

Source: 1977-2009 corn and gasoline prices from Commodity Research Bureau 2010 Yearbook. 2010-13 corn and gasoline prices from Index Mundi (2014). Corn and wheat planted acreage data from USDA ERS (2014a). US Producer Price Index from Global Financial Data; series code: WPUSAM. HFCS consumption data from USDA ERS (2014b). Meat consumption data from USDA ERS (2014c).

Through underhand advocacy efforts, ADM managed to secure key privileges and protections for the ethanol sector. ${ }^{1}$ Most notably, in the 1978 Energy Tax Act, a 40 cent tax exemption was granted to every gallon of ethanol mixed into gasoline and in the

\footnotetext{
${ }^{1}$ ADM continuously flirted with scandal in its search for benefactors. According to a deposition given by a former presidential secretary, Dwayne Andreas - then the Chief Executive Officer (CEO) of the company - personally delivered a package to President Nixon containing $\$ 100,000$ in $\$ 100$ bills in 1972. The cash was kept in a White House safe for around a year before being returned by Nixon when the Watergate scandal was beginning to engulf him (Carney 1995).
} 
1980 Omnibus Reconciliation Act, a 40 cent tariff was imposed on Brazilian ethanol. ADM also lobbied above board, via the ostensibly farmer-based commodity groups that had superseded the farm bloc. For example, at the beginning of Reagan's presidency, ADM joined with the American Sugar Alliance to campaign for increased government support for sugar farmers. The campaign was a success. In 1981 a bill was introduced that extended import quotas on sugar and raised the price-floor of domestically produced sugar to about double the world market price. Soon after the bill was passed domestic sugar prices predictably increased and, in response, Coca Cola and Pepsi ratcheted up their orders of HFCS (Milling \& Baking News 1984, 10). Partly as a result, American consumption of the sweetener surged (see right insert, Figure 2). The import quotas on sugar also bolstered the corn-ethanol sector, for sugar was widely used as an ethanol feedstock in Brazil, and sugarcane ethanol was proven to have a far superior energy conversion ratio to corn-ethanol. The US ethanol sector was thus now doubly protected: from ethanol imports and from the imports of a rival feedstock. As ADM's sweetener/alcohol complex accounted for $87 \%$ of ethanol production capacity in the US and $32 \%$ of HFCS production capacity, it enjoyed the bulk of the benefits (USDA ERS 1993, Henkoff 1990).

From a broad perspective then, the food regime approach is correct in arguing that the development of substitutable commodities, such as HFCS for cane sugar and ethanol-blended 'gasohol' for gasoline, can be considered as part of an overarching process through which capital overcomes barriers to accumulation in the agri-food system. But at the specific level of federal policy, the rise of the 'sweetener/alcohol complex' in the US can be seen as the result of an active restructuring of accumulation barriers. This restructuring created opportunities for ADM to increase its expected future earnings over and above other agri-food companies. Indeed, ADM not only jealously guarded itself from foreign competition through securing government tariffs and import quotas. It also barred potential rivals in the US from challenging its supremacy by pushing the purportedly sector-wide lobby group - the Renewable Fuels Association (RFA) - to dissuade the US Department of Energy from disbursing loan guarantees to start-up ventures (Henkoff 1990). By the late 1980s the company claimed a 75\% share of ownership of total US ethanol processing capacity (Weiss 1990). Thus, the corn-ethanol sector remained little more than a government-backed monopoly. In maintaining its control over much of ethanol production and in maintaining its influence over the major lobbying organization for the ethanol sector, ADM was well positioned to engage in more policy breakthroughs in the 1990s. Bribes (viz. campaign contributions) appeared to be a key component of the company's success. In the 1992 US Presidential election race, ADM was the largest single source of funding for George Bush Senior's reelection bid and the third largest single source of campaign funding for Bill Clinton. In just one campaign fundraiser organized by Andreas, $\$ 3.5$ million was raised for Clinton. Soon after Clinton was elected into office, he stipulated that $30 \%$ of fuel in America's nine most polluted cities be cut with ethanol, despite mounting evidence presented by his own advisors that the resulting gasohol fuel would lead to new environmental problems (Manning 2004, 27).

However, not everything was going ADM's way. As Figure 2 shows, during the 1990s the inflation-adjusted price of gasoline continued on a downward slope from the 
heights it reached at the beginning of the previous decade. Because ethanol prices were in effect tied to falling gasoline prices, the profit margins of the company's ethanol operations were squeezed (ADM 1994, 5). Moreover, the Asian Financial Crisis of 19978 greatly undermined ADM's export business. Up until that point East Asia represented a growing regional market for the company. But in the wake of the crisis, East Asian imports of the foodstuffs processed and transported by ADM fell dramatically. Dietary trends in the US compounded ADM's problems. The slowdown in per capita corn sweetener intake, as depicted in the right insert of Figure 2, was particularly worrisome for ADM because in the mid-1990s an estimated $40 \%$ of the company's profits were generated by its HFCS division (Kilman et al. 1995). In this context, ADM reevaluated its priorities. Up until the turn of the twenty-first century, ADM's ethanol operations were, despite all the government support, little more than an adjunct to its massive HFCS division. But this changed once per capita intake of HFCS began to taper off in the US. With widespread health concerns relating to HFCS and with ever more people switching from soft drink to bottled water consumption, ADM was clearly facing an uphill battle in pushing more corn syrup into American digestive space (Meyer 2005). It thus shifted its emphasis from increasing HFCS's 'stomach share' to increasing what I call ethanol's 'gas tank share'. ${ }^{2}$ Meanwhile, medium-sized alternative energy ventures were slowly making inroads into ADM's preponderance in the ethanol sector. This was evidenced by the fact that by the late 1990s, the company's share of control over national ethanol production capacity fell to $46 \%$ (Heffernan 1999). Moreover, by the turn of the millennium powerful agricultural input firms and an increasingly assertive cadre of American corn farmers also began to find reason to put their weight behind the pro-ethanol agenda. As such, the corn-ethanol industry grew from being the almost exclusive plaything of ADM, into a sector that was courted by a burgeoning array of interests within US agribusiness and agriculture. It is to these interests that we now turn.

\section{The Agro-Trader nexus versus the Animal Processor nexus}

Like ADM, many American corn farmers were weighed down by the price slump in global agricultural commodity markets in the late 1990s. In previous years, farmers could have relied on the US government to mitigate the price drops through the combined use of land idling requirements and public grain reserves. However, the 1996 Farm Bill effectively discontinued all instruments of price stabilization. And in so doing, the bill completed the process of disbanding production controls commenced by the 1973 Farm Bill. Farmers now received direct payments, not on the basis of the difference between 'target prices' and 'market prices', but rather on their past acreage use. With payments now completely decoupled from prices and production, farmers had a strong interest in reversing the price decline of their crops. This interest was particularly acute for corn growers who saw the price of corn fall by $48 \%$ in the three years that followed the bill's implementation - the largest price drop of any of the major agricul-

2 This shift was emblematized by the appointment of Patricia Woertz - former vice-president of the oil giant Chevron - as the CEO of ADM in 2007. 
tural commodities (Winders 2009, Commodity Research Bureau 2010, Lehrer 2010). Corn growers thus sought to find new ways of increasing the consumption of their output. Supporting ethanol production appeared to be an elegant solution. Millions of bushels of corn could be channelled into this growing sector and farmers could enjoy additional income through directly owning the plants that processed corn into ethanol. As such, in the late 1990s, a large number of farmer-owned ethanol cooperatives were formed. These cooperatives tenaciously lobbied state and federal governments to establish tax incentives and targets for the use of ethanol as a fuel additive (Ray 2009, 2010).

Three of the leading agribusiness input firms - Deere \& Co., DuPont and Monsanto - also put their weight behind the agrofuel sector. It is around the linkages between these agribusinesses and ADM that the Agro-Trader nexus took shape. The nexus emerged at a time when control over ethanol production was slowly becoming more decentralized, while control over the agricultural input industry was becoming increasingly concentrated. This rapid rise in concentration emerged against the backdrop of landmark legislation, such as the 1994 Plant Variety Protection Act, that strengthened corporations' capacity to assert exclusive ownership over the building blocks of plant reproduction (Mascarenhas and Busch 2006). Corporations were thus given license to further appropriate key aspects of the agricultural process. Since the mid-1990s, DuPont and Monsanto have been particularly active in staking their claims. In terms of gene technology, Monsanto is the clear leader. By 2009 over $80 \%$ of the planted acres of corn in the US contained genetic traits owned by the company (Langreth and Herper 2009). And in terms of control over the distribution of the seed itself, by 2010 Monsanto commanded a $36 \%$ share of the corn seed market in the US while DuPont had a $34 \%$ share (Kaskey 2010).

These agro-biotechnology giants have extensive reach into the halls of US government. Perhaps the most important aspect of this influence comes in the form of the 'revolving door', whereby corporate employees of the past become corporate regulators of the present, and vice versa. Many agri-food corporations employ this strategy of peddling policy. But no company has been better at keeping the door between government and business revolving than Monsanto. Examples of company personnel moving in and out of government are legion. To take just a few cases: former Monsanto attorney, Clarence Thomas, is now a Supreme Court Judge; former Monsanto Vice-President for Public Policy, Michael R. Taylor, is currently Senior Advisor at the Food and Drug Administration; and former Monsanto and DuPont lobbyist, Islam A. Siddiqui, is the incumbent Chief Agricultural Negotiator for the US in international trade talks. Moving in the opposite direction: former Director of Agricultural Affairs at the Office of the US Trade Representative, Melissa Agustin, is now a lobbyist for Monsanto; and former Deputy Chief of Staff at the USDA, Jeremy Stump, is now Monsanto's Director of Government Relations (Boschma 2013, Center for Responsive Politics 2013). Keeping track of the many loyal purveyors of corporate power swinging in and out of public office may prove dizzying; but the point is that, through the revolving door, the seed giants are in effect regulating the very institutions that are meant to be regulating them. And as a consequence, their accumulation strategies are becoming progressively more synergized with the machinations of government (Baines 2014). 
Monsanto and DuPont have used their considerable influence to push for the expansion of the corn-ethanol sector for four main reasons. Firstly, as has been noted, the two companies have unsurpassed control over the reproduction of corn in the US. Secondly, because many of their corn varieties are bioengineered to withstand the application of broad-spectrum herbicides, such as Monsanto's RoundUp product, seed sales are also tied in with agrochemicals sales for the major agro-biotechnology firms. Thirdly, of all the major commodity crops, corn requires the most chemically intensive production methods and this, in turn, further boosts Monsanto's and DuPont's revenues. ${ }^{3}$ Fourthly, an expanding ethanol sector appeared to be an expedient means of bolstering the consumption of GM corn in the context of the decline of HFCS intake discussed above. Finally, wheat farmers have heretofore successfully resisted the commercialization of Monsanto's GM wheat, thus underscoring corn's status as the ultimate agribusiness crop (see Falkner 2009). The seed giants' commitment to corn-ethanol was revealed at the beginning of the agrofuel boom. In the early 2000s, DuPont developed a hybrid seed screening initiative to determine which strains of corn will yield the most ethanol per acre (Butzen and Haefele 2008). Similarly, Monsanto launched a 'Fuel your Profits' seed program geared to breeding corn that could be more easily fermented into ethanol (Monsanto 2003).

The agricultural machinery firm, Deere \& Co., has also actively supported the development of the ethanol sector. This support is in part due to the fact that soaring corn-ethanol production bolsters corn prices, which in turn increases the cash flow of the company's main customers: commercial crop farmers. Thus, Deere wagered that the ethanol boom would stimulate the increased purchase of specialized farm vehicles and equipment (Tepe et al. 2011). And as the company commands a $46 \%$ market share over the agricultural machinery sector in the US, it would be the major beneficiary (UOIG 2012, 7). In 2008, Deere underlined its commitment to the agrofuel boom by joining ADM, DuPont, Monsanto and the RFA to create the 'Alliance for Abundant Food and Energy' - a lobbying group that advocates extensive government support for ethanol and biodiesel. With the formation of this alliance, the Agro-Trader nexus crystallized into a distinct institutional form (Cameron 2008). As the left side of the network diagram in Figure 3 shows, the Agro-Trader nexus encompasses many organizations, from groups representing corn farmers (the National Corn Growers Association), to railroad interests (the Union Pacific Railroad), to oilseed processors (Bunge). However, the main axis of power within this constellation of social forces is constituted by the four founding firms of the 'Alliance for Abundant Food and Energy', shaded in grey: ADM, Deere \& Co., DuPont and Monsanto.

The corporate appropriation of various aspects of commodity crop production has been mirrored by the corporate appropriation of the phases through which animal life is converted into consumer meat products. The increased concentration of control over

\footnotetext{
${ }^{3}$ Indeed, on average, farmers spend up to US $\$ 15$ per acre more on pesticides for corn production than they spend on soybean production, and almost US $\$ 40$ per acre more on pesticides than what they spend for wheat production (Purdue Extension 2013). Furthermore, as soaring ethanol production encourages the abandonment of crop rotation in favor of growing corn on the same land year after year, the chances of pest infestation are heightened, and this, in turn, increases farmer dependency on the 'biophysical overrides' provided by the agri-biotech giants (Weis 2010).
} 


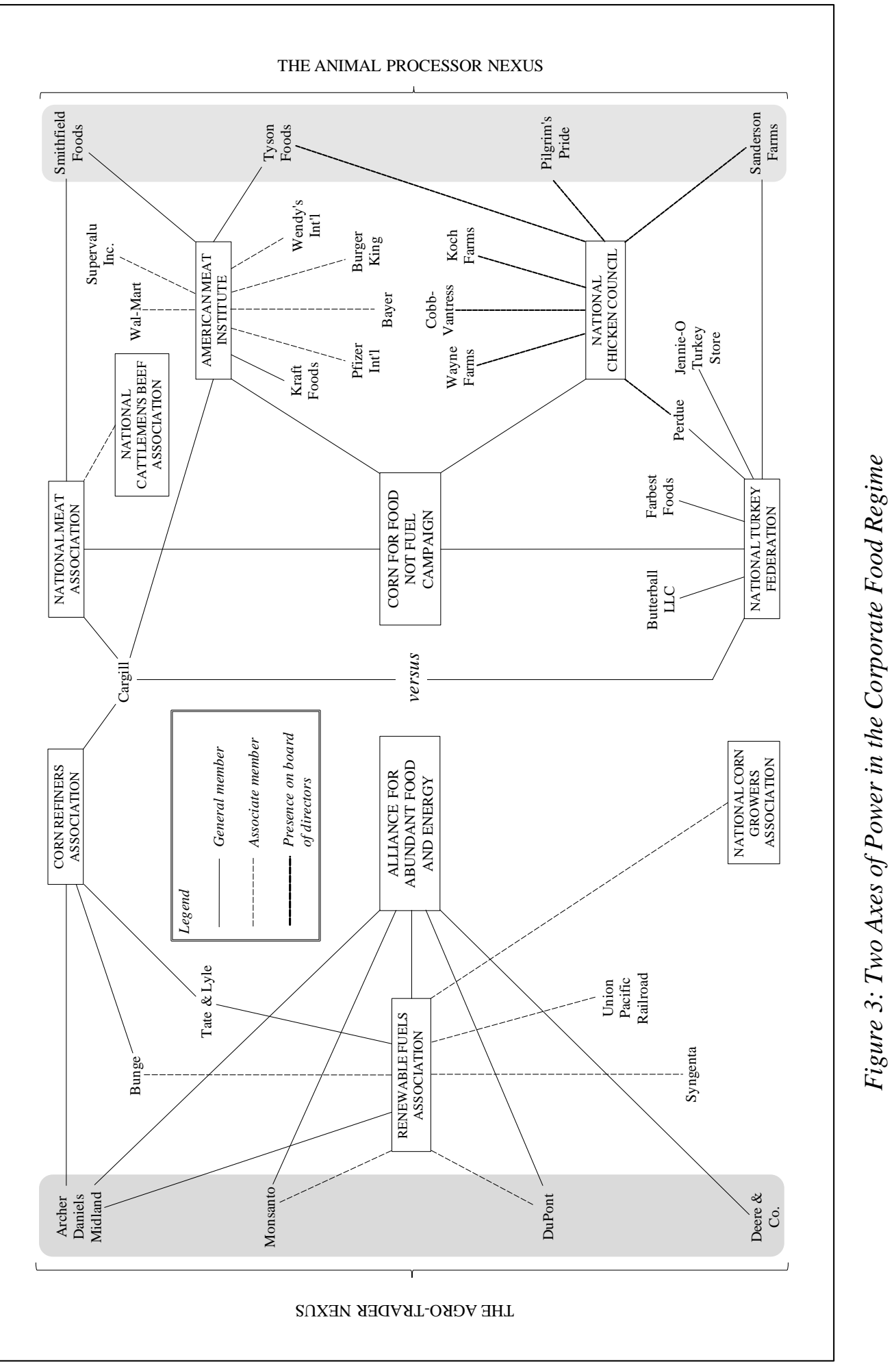


the livestock-feed complex is partly indicated by the fact that the market share of the four largest firms in the US meat packing sector rose from a post-war low of $19 \%$ in 1977 to 59\% just 25 years later (US Census Bureau 2013). Table 1 relays the latest obtainable data on meat company shares over animal kill in the US and it also puts the slaughtering of American domesticates within a global context. Although startling, the figures presented in the table do not tell us anything about the amount of control that major meat companies wield over animals prior to their death and dismemberment. In fact, some of the companies listed in the table have appropriated control over the very reproduction of animal life. In a process that mimics the development of hybrid crops, these meat companies have engaged in the crossing of different pure-bred lines of animals so as to optimize certain genetic traits that conduce to greater and more predictable earnings. As the offspring of hybrids do not reproduce the same traits found in animals conceived from the initial crossing of 'nucleus herds', farmers return to the cross-breeders to replenish their stock of animals (Fuglie et al. 2011). ${ }^{4}$

\begin{tabular}{|c|c|c|c|c|}
\hline & $\begin{array}{l}\text { Number } \\
\text { slaughtered in the } \\
\text { world annually }\end{array}$ & $\begin{array}{c}\text { Number } \\
\text { slaughtered in the } \\
\text { US annually }\end{array}$ & $\begin{array}{l}\text { Four Largest } \\
\text { Firms in the US }\end{array}$ & $\begin{array}{c}\text { Share of US animal } \\
\text { slaughter }(\%)\end{array}$ \\
\hline Chickens & 59.9 billion & 8.7 billion & $\begin{array}{l}\text { 1. Tyson Foods } \\
\text { 2. Pilgrim's Pride } \\
\text { 3. Sanderson Farms } \\
\text { 4. Perdue Farms }\end{array}$ & $\begin{array}{r}21 \\
18 \\
7 \\
7\end{array}$ \\
\hline Turkeys & 649.5 million & 250.1 million & $\begin{array}{l}\text { 1. Butterball } \\
\text { 2. Jennie-O Turkey } \\
\text { 3. Cargill VA Meats } \\
\text { 4. Farbest Foods, Inc. }\end{array}$ & $\begin{array}{r}19 \\
18 \\
15 \\
6\end{array}$ \\
\hline Pigs & 1.4 billion & 107.5 million & $\begin{array}{l}\text { 1. Smithfield Foods } \\
\text { 2. Tyson Foods } \\
\text { 3. JBS Swift } \\
\text { 4. Cargill }\end{array}$ & $\begin{array}{r}26 \\
17 \\
11 \\
9\end{array}$ \\
\hline Cattle & 295.5 million & 31.9 million & $\begin{array}{l}\text { 1. Tyson Foods } \\
\text { 2. JBS USA } \\
\text { 3. Cargill } \\
\text { 4. Nationa Beef Packing }\end{array}$ & $\begin{array}{l}23 \\
21 \\
20 \\
11\end{array}$ \\
\hline
\end{tabular}

Table 1: Animal Slaughter and Corporate Control

Note: Global and US slaughter figures as of 2012. Market share data for chicken slaughter as of 2014. Market share data for turkey, cattle and pig slaughter as of 2013.

Source: Global and US animal slaughter figures from FAOSTAT 2014. Market share data for chickens, turkeys, pigs and cattle presented in Watt Poultry 2014, Pork Checkoff 2013 and Cattle Buyers Weekly 2013 respectively.

\footnotetext{
${ }^{4}$ The growing corporate control over the lives of American domesticates has been particularly pronounced in the poultry sector. The largest poultry firm, Tyson Foods, commands a 60 percent market share of the US chicken breeding stock (Food Safety Magazine 2007).
} 
As a result of the ongoing corporate appropriation of discrete phases of farm production, agribusiness control over agriculture has become simultaneously highly consolidated and bifurcated. By the turn of the millennium, a small group of oligopolistic firms superintended the production and processing of commodity crops and a small group of oligopolistic firms commandeered the conversion of animals into meat products. As corn growers increasingly became reduced to being providers of feed inputs for the livestock-feed complex, fewer and fewer raised their own livestock. The diminution of integrated livestock-crop farming made investing in ethanol cooperatives the best alternative source of 'value-added' for corn farmers (Ray 2009). Furthermore, by promoting and facilitating the diversion of grain from the feed sector, the Agro-Trader nexus appeared to have sought to gain leverage over the major meat companies. It was in this context that the 2005 Renewable Fuel Standard (RFS) was implemented. The RFS mandated the blending of 7.5 billion gallons of agrofuel into America's gasoline supply by 2012. In 2007 the food/fuel complex was further bolstered by the US Energy Independence and Security Act. This piece of legislation increased the RFS to 15 billion gallons of corn-ethanol by 2015 .

The enactment of the ethanol mandates caused massive re-channelling of domestically produced corn away from the livestock-feed complex toward the food/fuel complex. As Figure 4 shows, the ethanol sector's share of total corn produced in the US rose from just $6 \%$ in 2000 to over $40 \%$ in 2012. Meanwhile, the share of corn used by the livestock-feed complex plunged. The turning point appears to have been 2005, when the ethanol mandate was first introduced. At the height of the ethanol boom, from 2005 to 2012, the share of total corn produced in the US for feed fell from 58\% to $36 \%$. Given that $90 \%$ of feed grain used in the animal processing sector is corn-based; and given that feed comprises $60-70 \%$ of livestock production costs, the diversion of corn into ethanol distilleries has had a huge impact on the meat business (Becker 2008). The effect is confirmed by the insert of Figure 4. As the graph shows, the falling share of corn used for meat production from 2005 onwards has coincided with a structural shift in feed grain prices relative to meat prices. Moreover, the structural shift appears to be particularly stark in the hog and poultry sectors. From 1985 to 2005 a pound of pig meat cost around twenty times more than a pound of corn and a pound of chicken meat cost around five times more than a pound of chicken feed. But by 2012, a pound of pig meat cost just ten times more than a pound of corn and a pound of chicken meat was just three times more expensive than a pound of chicken feed. Although animal feed price ratios within the beef sector have historically been more cyclical than the poultry and hog sectors, a sharp fall in the steer and heifer to corn price ratio can also be seen from 2005 to 2012. The precipitous drops in the meat price-feed price ratios during these seven years were driven by soaring corn prices. Indeed, in this period, inflationadjusted corn prices increased by $215 \%$, while inflation-adjusted average meat prices increased by merely $7 \% .^{5}$

\footnotetext{
${ }^{5}$ Author's own calculations. Meat prices and corn prices deflated by the consumer price index. Data from BLS (2014a,b,c).
} 


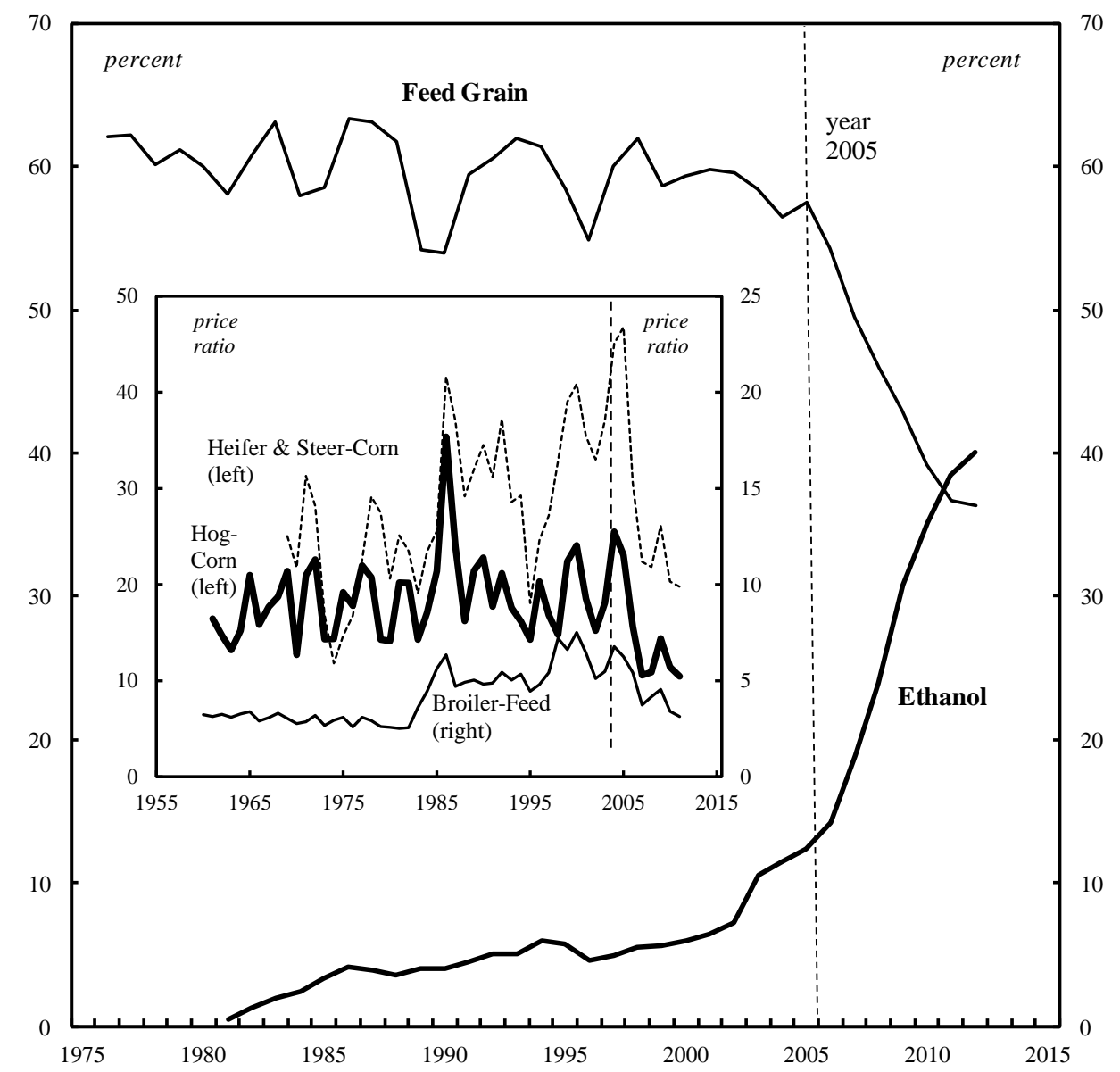

Figure 4: Proportion of Domestically Produced Corn used by Feed Grain and Ethanol Sectors

Note: The feed price - meat price ratios weigh the price of feed per pound against the per pound price of meat.

Source: Feed price - meat price ratios from USDA ERS (2014a). Corn use data from USDA ERS (2014d).

The dramatic price shifts coincided with sharply contrasting pronouncements made in regard to the effects of the ethanol sector on the meat business. Indeed, in 2006, the then CEO of ADM, G. Allen Andreas, bluntly stated: ' $[t]$ here is no consumption versus combustion debate, except for those who really do not recognize the realities of the way this business functions' (Milling \& Baking News 2006, 11). The CEO of Tyson Foods, Dick Bond, did not recognize the 'realities' that his counterpart at ADM was referring to. In fact, Bond could hardly contain himself when remonstrating against the ethanol sector: 'I can rant and rave about this for some time, but some of the things that our government in Washington has done in terms of mandating the use of corn-based ethanol... it's not right' (Mosely 2008). Similarly, in an op-ed for the Wall Street Jour- 
nal, Larry Pope - the CEO of Smithfield - argued that the US government's mandate on ethanol blending had a more grievous effect in terms of increasing corn prices in 2012 than the deleterious drought of that year. '[I]f the ethanol mandate did not exist', Pope moaned, 'even this year's drought-depleted corn crop would have been more than enough to meet the requirements for livestock feed and food production at decent prices' (2012). Such is their animus toward the RFS, interest groups within the US livestock sector have even set up a 'Corn for Food not Fuel' campaign to encourage concerned consumers to join them in their movement against corn-ethanol. ${ }^{6}$

As Figure 3 indicates, the Corn for Food not Fuel campaign is headed by four major meat business lobbying groups: the American Meat Institute, the National Meat Association, the National Chicken Council and the National Turkey Federation. It is around this network of advocacy organizations that a new corporate-led distributional coalition - the Animal Processor nexus - can be seen to take shape. Whereas the Agro-Trader nexus encompasses a fairly narrow set of groups that operate upstream in agricultural supply chains such as seed firms, corn growers and trading firms; the Animal Processor nexus is part of a broader and more diffuse constellation of interests that operate further downstream in supply chains. But the axial firms in the Animal Processor nexus are the major meat packing companies: Tyson Foods, Smithfield Foods, Pilgrim's Pride and Sanderson Farms. Their dominance in the livestock-feed complex is attested to by their shares in overall animal slaughter (see Table 1), and it is also affirmed by the fact that they are the four largest meat packers headquartered in the US by market capitalization.

The charges and counter-charges between key figures in the US agri-food sector clearly point to polarized opinions amongst the agribusiness elite. And the emergence of the Alliance for Abundant Food and Energy and the Corn for Food not Fuel campaign is also indicative of a deepening cleavage within US agri-food capital. But what connections, if any, can we draw between these recriminations and alliances, on the one hand, and distributional shifts in accumulation, on the other? Figure 5 presents the contrasting pecuniary trajectories of the axial firms of the Agro-Trader nexus and the axial firms of the Animal Processor nexus. Drawing on methods developed by Jonathan Nitzan and Shimshon Bichler (2009), I gage the Agro-Trader nexus's and Animal Processor nexus's pecuniary trajectories through dividing the average per firm capitalization of each axis of power relative to the average per firm capitalization of the top 500 corporations listed in the US, ranked by market value for each quarter. The right insert presents the Agro-Trader nexus's and Animal Processor nexus's differential

\footnotetext{
${ }^{6}$ Cargill holds an ambiguous position in regard to the 'feed versus fuel' debate. On the one hand, it has played a significant role in supporting the ethanol sector, not only through developing hybrid corn and bioengineered corn for ethanol production, but also by opening up its own ethanol plants. Indeed, at the turn of the twenty-first century, it had the fifth largest share of control over the sector (Heffernan1999). On the other hand, Cargill's more substantial interests in consumer food and animal feed markets have made the company reluctant to lend its full backing to ethanol production. This reluctance was evidenced in a statement by Cargill's CEO, Warren Staley, in which he advocated 'a hierarchy of value for agricultural land use: food first, then feed and last fuel' (cited in Milling and Baking News 2006, 11). By straddling the Agro-Trader nexus and the Animal Processor nexus and by adopting a comparatively equanimous position in the 'feed versus fuel debate', Cargill is the exception that proves the rule.
} 
markup. This is calculated by dividing the net income to sales ratios of each corporate grouping by the weighted average of the net income to sales ratio of the top 500 USlisted firms. Thus, while the main chart in the figure depicts changes in investors' collective appraisal of the future earnings potential of the Agro-Trader nexus and the Animal Processor nexus, the right insert depicts changes in the corporate constellations' relative profit margins. The left insert switches the focus from the shifts in the differential capitalization and differential markup within agribusiness to the redistribution of income within agriculture. The differential income of corn growers and livestock farmers is calculated by dividing their respective average net incomes each year by the corresponding net income of all farmers in the US. The average net income data of livestock farmers is the weighted average of the net income of cattle farmers, hog farmers and poultry farmers.

Three major observations can be made from the figure. Firstly, the market capitalization of the Agro-Trader nexus is greater than that of the Animal Processor nexus by an order of magnitude of around ten. Secondly, as the trendlines suggest, while the Agro-Trader nexus has accumulated ever since the onset of the ethanol boom, the Animal Processor nexus has experienced a general pecuniary decline. Thirdly, in addition to these general trends, there are interesting oscillations in the differential capitalization of both the Agro-Trader nexus and the Animal Processor nexus. The Animal Processor nexus experienced a significant pecuniary upsurge in 2004 and 2005, when meat consumption and meat price-feed price ratios reached high-points (see Figure 2 and Figure 4). However, from 2006 to 2010 - when ethanol production soared and when meat price-feed price ratios plummeted - the Animal Processor nexus's differential capitalization dropped almost uninterruptedly. And when the Agro-Trader nexus reached its pecuniary zenith in 2009, the differential capitalization of the Animal Processor nexus was well on its way to reaching a nadir.

Similar patterns can be seen in the differential income data of corn growers and livestock farmers. In terms of magnitudes, from 1996 onwards corn farmers have enjoyed incomes that are on average almost six times larger than their counterparts in animal agriculture; and in terms of the changes in these magnitudes, the shifts in the differential incomes of corn farmers and livestock farmers are broadly synchronized with the axes of power in which they are enfolded. The differential incomes of livestock farmers reached a peak around 2005 just like the differential capitalization of the Animal Processor nexus; and like the capitalized profit shares of the Animal Processor nexus, the livestock farmers' income share bottomed out in 2008 only to increase again from 2009 onwards. Moreover, similar to the Animal Processor nexus, the livestock farmers experienced a general decline in relative pecuniary earnings in the period covered by the data. Contrariwise, the differential income of corn growers has trended upward since the beginning of the twenty-first century, just like the differential capitalization of the Agro-Trader nexus. Additionally, the corn growers' relative earnings reached an apogee in 2008-9 - the very same time that the differential capitalization of the Agro-Trader nexus climaxed.

The general synchronicity between the relative pecuniary earnings of the AgroTrader nexus and the corn growers on the one hand, and the Animal Processor nexus 
and the livestock farmers on the other, suggests that the redistribution of capitalized profits within agribusiness is tightly connected to the redistribution of income within

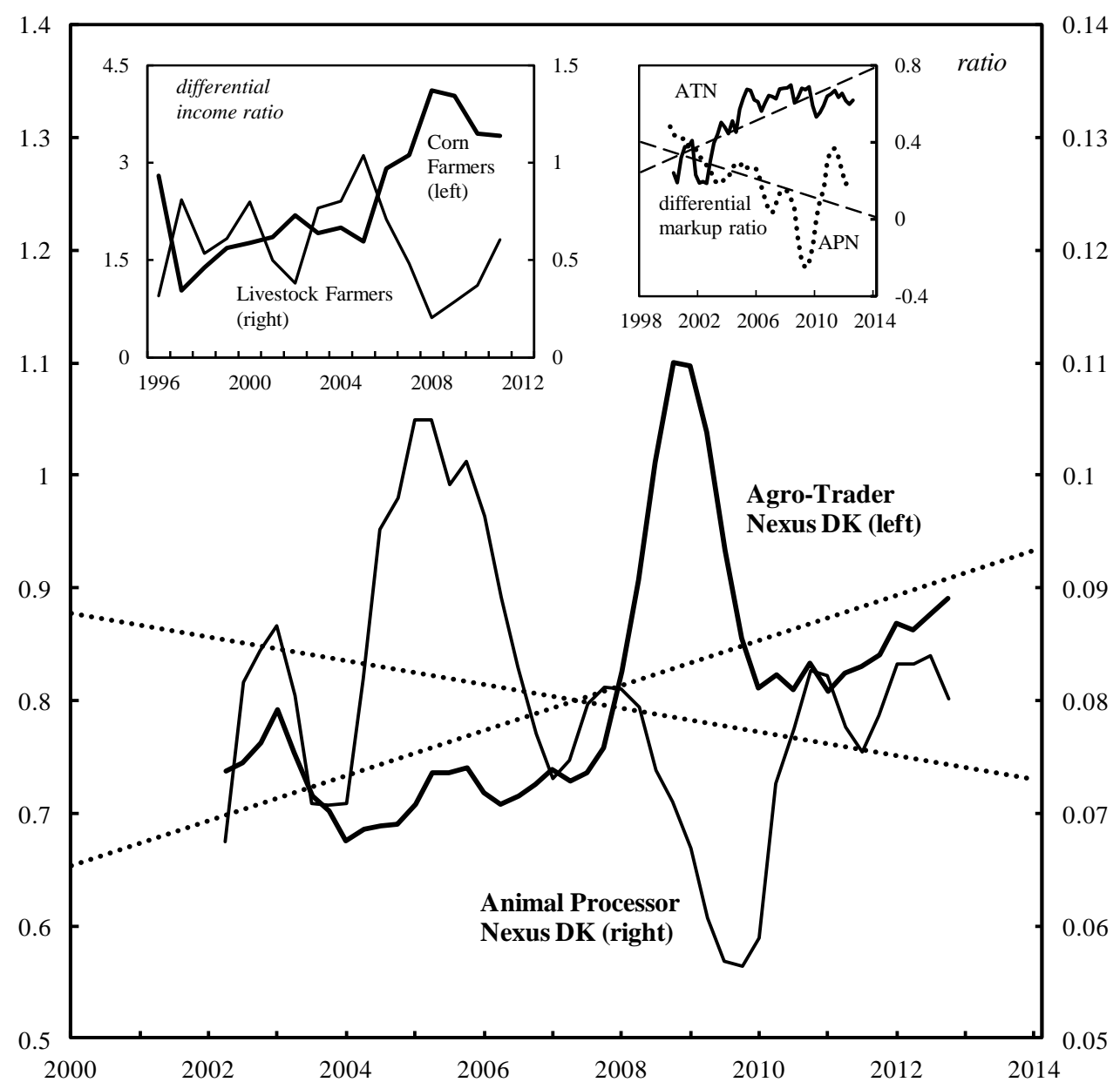

Figure 5: The Differential Capitalization (DK) of the Agro-Trader nexus and the Animal Processor nexus

Note: The differential capitalization and differential markup of the Agro-Trader nexus and Animal Processor nexus is presented as one-year moving averages. 'Livestock farmers' is a composite category comprising cattle, hog and poultry farmers, weighted by farm population size. Given DuPont's wide ranging activities, only its agricultural division's net income and revenue data were included in the calculation of the Agro-Trader nexus's differential markup.

Source: Company market capitalization from Compustat through WRDS. Archer Daniels Midland, Deere \& Co. and Monsanto net income and revenue data from Compustat through WRDS. DuPont's agricultural division net income and revenue data from 10-K SEC filings. Farmer net income data from the USDA NASS (2013).

agriculture. This insight is important because extant food regime accounts of agrofuels tend to examine the power dynamics between agri-food capital and agricultural pro- 
ducers. In contradistinction, the analysis offered here cuts across the agribusiness/agriculture divide to show how one cluster of farmers and agri-food corporations appears to be benefiting at the expense of another. Therefore, to use the words of White and Dasgupta cited in the introduction of this paper, we can make more incisive claims about 'the structures of accumulation or (dis)accumulation' and the 'accompanying processes of social differentiation' in the agrarian political economy of the US. In terms of the structures of accumulation and (dis)accumulation, the Agro-Trader nexus has been accumulating rapidly for much of the early twenty-first century, while the Animal Processor nexus has been generally dis-accumulating. And in terms of social differentiation, the divergent pecuniary trajectories outlined here point to the opening of a significant chasm between corn growers, on the one side, and livestock farmers, on the other.

ADM's heightened capacity to re-channel corn into the ethanol sector allowed it to exact more favorable prices for the feed inputs it renders to the Animal Processor nexus. The Agro-Trader nexus also capitalized on the control that it wields further upstream in food supply chains. Indeed, Monsanto and DuPont have used their combined $70 \%$ market share over the corn seed market and their unsurpassed control over plant genetics to capitalize on the ethanol surge. More and more land that used to be committed to wheat production has been turned over to corn production (see right insert of Figure 2). And as GM corn acreage has eaten into non-GM wheat acreage, farmers have increasingly drawn upon inputs, such as RoundUp herbicide and RoundUp Ready corn, sold by the seed giants. Deere \& Co. also appeared to benefit from the corn price boom. Farmers were newly flush with cash and were thus more willing to purchase Deere's highly expensive specialized machinery and equipment (Blumenthal 2012). The enhanced relative profitability of the Agro-Trader nexus's operations is registered in the steady rise in its differential markup during the agrofuel boom, as presented in the right insert of Figure 5.

It is worth noting that the corn used by the ethanol sector is not entirely diverted from the livestock-feed complex as an animal feed called dried distillers' grains (DDGs) is an important bi-product of the ethanol production process. Nonetheless, a good deal of skepticism is felt in regard to its value as an input in animal agriculture. This skepticism is in part born out of the fact that the price of DDGs moves in tandem with the price of corn and when the inferior energy and nutritional content of distillers' grains are factored into calculations of its price, it does not appear to be much cheaper than corn feed itself. Opposition to the use of the ethanol bi-product is most trenchant in the poultry sector. Indeed, chicken farmers usually limit DDGs to $5 \%$ of the overall feed ration because of the limited capacity of birds to digest the input. As the President of the poultry lobbying group, the National Chicken Council, demurred:

'[T]his lesser feed is not coming at the discount that corn farmers and the ethanol industry would have you believe. Though DDGs provide a 25 percent "savings" compared to corn feed, that discount is nullified when considering the 275 percent spike in overall corn prices brought on by the RFS. Think of it as a grocery store raising prices by a couple of dollars then trying to win you over with a 50-cent coupon.' (Brown 2013) 
As I have already indicated, corn's status as the premier source of energy in the livestock-feed complex is indicated by the fact that it accounts for $90 \%$ of the grains consumed by livestock in the US. Given that chickens, and even pigs, have a limited ability to feed on other commercial sources of energy such as DDGs, poultry and hog operations are left particularly exposed to upswings in corn prices. This exposure is evidenced by the fact that during the two years from 2006 to 2008 when the cost of feed increased by two-thirds, and corresponding live-production costs increased by $80 \%$, the portion of corn in chickens' overall diets held constant (NCC 2013).

Notwithstanding these observations, in the cattle sector there is less criticism of DDGs. In fact, as ruminants are much more able to digest distillers' grain, it can comprise up to $50 \%$ of cattle feed formula. Overall the cattle sector is estimated to account for $75 \%$ of total domestic consumption of DDGs (Fatka 2011). Interestingly, however, the mitigating effects of DDGs on the inflationary impact that the ethanol boom has had on feed prices have been most pronounced for the livestock farmers that remain in the Corn Belt. Indeed, as approximately $85 \%$ of ethanol production capacity is concentrated in the Midwest, farmers in the Corn Belt can access DDGs at a lower cost than those farmers in other parts of the US. The differential expense advantage that they enjoy derives from the fact that, in this current period of relatively high energy prices (see Figure 2), it is costly to transport DDGs. Moreover, due to the $15 \%$ moisture content of DDGs, the ethanol bi-product is liable to deteriorate if it travels long distances. Given the transportation costs and the spoilage concerns, most distillers' grains are used by farms that are situated within a $100 \mathrm{~km}$ radius of the ethanol plant from which the biproduct has been churned out (Gottschalk 2007). These insights regarding the uneven effects of distillers' grains suggest that the ethanol boom in the US has not only redistributed income from the livestock sector to the corn sector; in fact, it may have also redistributed income within the livestock sector, from farmers outside of the Corn Belt, to those inside it.

The great divergence within agriculture between farmers inside the Corn Belt and farmers outside of the Corn Belt, and the coeval schism between the Agro-Trader nexus and the Animal Processor nexus, has been mirrored by a growing divide on Capitol Hill. In the mid-2000s, when national gasoline consumption was still on the increase and when the US army was still deeply engaged in its Iraq adventure, politicians representing Corn Belt states enjoyed a broad-base of congressional support for their initiatives to bolster the ethanol sector. Considerations of 'energy security' reigned supreme. However, from 2007 onwards national gasoline consumption has decreased due to improved automobile efficiency and a decline in travelling by recession-hit drivers. Moreover, the widespread introduction of hydraulic fracturing ('fracking') has opened vast shale fields for oil extraction. As a result of these developments, ethanol increasingly appears to be the panacea of yesteryear. Members of Congress representing Corn Belt states still staunchly promote US government support for ethanol, as their interests are intertwined with the agribusiness-agricultural constituencies that they represent. Nonetheless, they have found themselves fending off a counter-movement headed by political representatives of major meat producing states such as Arkansas, Alabama, Georgia and Texas. Although these states have failed so far in their attempts to attain RFS waivers, they have enjoyed legislative breakthroughs in other areas. Most notably, 
in 2012 the US Congress voted to discontinue two bulwarks of the ethanol sector secured by ADM three decades ago: tariffs on imported ethanol and the tax credit for ethanol blenders.

The slowing growth in the diversion of corn into the ethanol sector (Figure 3) contributed to a brief deflationary period within US grain markets. The price adjustments have benefitted the Animal Processor nexus and disadvantaged the Ago-Trader nexus. In the context of slumping corn prices, there was a farmer backlash against Monsanto's genetically engineered SmartStax corn seed as the high price the company charged for it seemed to be completely unreasonable given its indifferent yield performance. Monsanto claims that it has now adjusted its pricing model. According to Monsanto's own figures, toward the end of the first decade of this century, the company sought to garner $50 \%$ of the extra profit that the introduction of its newly engineered seeds generated for farmers. Now, they have reverted back to their strategy of claiming one-third of the extra profits (Pollack 2010). The moderation in Monsanto's pricing strategies perhaps contributed to the flat-lining in the differential markup of the Agro-Trader nexus in recent years, as depicted in the right insert of Figure 5. ADM, for its part, found that the margins of its ethanol processing division were caught in a cost-price squeeze due to the diminution in the differential between gasoline prices and corn prices, as depicted in Figure 2 (Blas 2012). Finally, Deere \& Co. experienced reduced sales of its specialized crop agriculture vehicles, as falling crop prices reduced corn growers' willingness to make costly machinery purchases. As a result of these counter-currents, the great divergence from 2008 to 2009 in capitalized profit shares within agribusiness, and in income shares within agriculture, has been followed by considerable re-convergence in both differential capitalization and differential income trends. But despite the apparent modulation in distributional dynamics, if the ethanol sector continues to consume around two-fifths of the corn produced in the US, the upward pressure that US agrofuels put on global grain prices will persist in rendering the populations of importdependent countries vulnerable to food price hikes.

\section{Conclusion}

Building on previous scholarship in agrarian political economy (Goodman et al. 1987), the food regime approach underscores the importance of the corporate appropriation of discrete phases of agricultural production, on the one hand; and the reconstitution of perishable foods into substitutable commodities, on the other. As Friedmann and McMichael argue, these processes of appropriation and substitution have eroded the autonomy of farmers over the agricultural process and they have also undermined the capacity of different governments to direct agriculture for national ends (1989). In the account offered here, I have sought to emphasize another major consequence of the decomposition of the world food system into discrete sectors: it can give rise to antagonism between corporate constellations that superintend different agri-food complexes. With this consideration in mind, I have examined the rivalry between the Animal Processor nexus and the Ago-Trader nexus. While the former has appropriated control 
over distinct parts of animal-meat production, the latter has extended its pecuniary ambit over distinct parts of corn and ethanol production.

Additionally, by underscoring the seemingly indispensable role played by corn for both of these axes of power, my analysis shows how processes of substitution can drive conflict between different groups of agri-food corporations and between different groups of farmers. In the case of the US agrofuel boom, the dramatic increase in the substitution of petroleum for ethanol completely overwhelmed most livestock farmers' rather limited capacity to replace corn with cheaper commercial feed. Moreover, the substitution of petroleum for ethanol has left the Agro-Trader nexus's accumulation strategies increasingly exposed to the vicissitudes of the global oil markets, and it has left the world's landless poor increasingly vulnerable to the vagaries of US energy policymaking.

The method of disaggregation advanced in this paper offers novel answers to some foundational questions within agrarian political economy regarding (dis)accumulation and social differentiation. On a macroscopic level, the agrofuel boom may have increased the profitability of capital in general, as McMichael contends. But within the US, the agrofuel boom can also be characterized as a vector of redistribution. The redistributional dynamics are multi-dimensional. By triggering the massive diversion of corn from the livestock-feed complex toward the food/fuel complex, the corn-ethanol boom shifted capitalized profit shares within agri-food capital, from the Animal Processor nexus to the Agro-Trader nexus. It also redistributed income within agriculture, from livestock producers to corn growers. Finally, the ethanol boom may have contributed to a shift in earnings within the livestock sector: from livestock farmers outside of the Corn Belt to livestock farmers inside the Corn Belt. As these redistributional shifts redound across the entire global political economy of food, my analysis underscores the conflicts at the heart of the corporate food regime, and the limits and contradictions of agrofuels capitalism at large.

In presenting these findings, the paper points to the potential of conducting further research that inquires into the ways in which redistributional struggles between farmers become co-articulated with redistributional struggles between agri-food corporations; and it points to the importance of analyzing how these struggles impact nourishment outcomes. Such research may deepen our analysis of uneven agrarian development and it may nuance existing understandings of the relations of inclusion and exclusion, and resistance and incorporation, between farmers in advanced capitalist countries, global agri-food corporations and the landless poor. Furthermore, in specifying the winners and losers of the agrofuel boom, the paper points to the social forces that stand in the way of change within the corporate food regime. As my findings indicate, putting an end to corn-ethanol production would not only involve challenging the accumulation strategies of some of the most powerful agri-food corporations in the world, it would also necessarily entail confronting the interests of more than 400,000 corn farms in the US, many of which have a direct stake in the continued diversion of their output into agrofuel feedstocks (EPA 2013).

Finally, the analysis underlines the importance of supporting farmer-led movements that operate at the margins of the corporate food regime. As activists, food regime analysts and agrarian political economists in this journal have long argued, locally-oriented 
polycultures, and peasant farming more generally, offer a vital alternative to the destructive directions in which agri-food corporations are taking the world food system. In defending and advancing these forms of agriculture, we may be able to move away from a food regime that commits inordinate amounts of energy and resources to fuelling cars and feeding intensively reared animals, towards systems of provisioning that are fundamentally centered on nourishing humans.

\section{Acknowledgments}

I would like to thank Jonathan Nitzan, Mark Peacock, Peter Gibbon and the two anonymous reviewers for their very helpful comments. Moreover, I am extremely grateful to Daniel Lech of the National Agricultural Library in Beltsville, Maryland for granting me access to the invaluable archival material at the library during four research trips from 2012-2013. Thanks are also due to Eric George, Jeremy Green, Sandy Brian Hager and David Ravensbergen. Finally, I would like to acknowledge Ontario's Ministry of Training, Colleges and Universities for awarding me an Ontario Graduate Scholarship in support of my research. The usual disclaimers apply.

\section{Bibliography}

ADM, 1994. 1994 annual report. Retrieved from ProQuest Annual Reports.

AgMRC 2014. Ethanol usage projections \& corn balance sheet. Agricultural Marketing Resource Center, 19 Feb. https://www.extension.iastate.edu/agdm/crops/outlook/cornbalancesheet.pdf [Accessed 21 March 2014].

American Meat Institute (AMI) 2014. General members. Available from: http://www.meatami.com/ht/d/sp/i/2343/pid/2343 [Accessed 20 June 2014].

Ariza-Montobbio, P., S. Lele, G. Kallis and J. Martinez-Alier. 2010. The political ecology of jatropha plantations for biodiesel in Tamil Nadu, India. The Journal of Peasant Studies, 37(4), 875-97.

Bain, C., A. Prokos and H. Liu. 2012. Community support of ethanol plants: does local ownership matter? Rural Sociology, 77(2), 143-70.

Bain, C. and T. Selfa. 2013. Framing and reframing the environmental risks and economic benefits of ethanol production in Iowa. Agriculture and Human Values, (30), 351-64.

Baines, J. 2014. Food price inflation as redistribution: towards a new analysis of corporate power in the world food system. New Political Economy. 19(1), 79-112.

Becker, G.S. 2008. Livestock feed costs: concerns and options. CRS Report for Congress, 17 Sept. Available from: http://congressionalresearch.com/RS22908/document.php?study=Livestock+Feed+Costs+Conce rns+and+Options [Accessed 21 March 2014].

Blas, J. 2012. Ethanol margins squeeze ADM's profits. Financial Times, 1 May. Available from: http://www.ft.com/cms/s/0/ea0e3542-938c-11e1-8c6f-00144feab49a.html\#axzz2woT6pkyj [Accessed 21 March 2014].

Blumenthal, R. 2012. Big green finds fertile fields abroad. Barron's, 24 Mar. Available from: http://online.barrons.com/article/SB5000142405311190464670457729378236862246.html [Accessed 31 August 2013].

Borras Jr. S.M, P, McMichael and I. Scoones. 2010. The politics of biofuels, land and agrarian change: editors' introduction, The Journal of Peasant Studies, 37:4, 575-592. 
Borras Jr. S.M., D. Fig and S.N. Suárez. 2011. The politics of agrofuels and mega-land and water deals: insights from the ProCana case, Mozambique, Review of African Political Economy, $38(128), 215-234$.

Boschma, J. 2013. Monsanto: big guy on the block when it comes to friends in Washington. Open Secrets Blog. Available from: http://www.opensecrets.org/news/2013/02/monsanto.html [Accessed 21 March 2014].

Brown, M. 2013. No doubt about it: ethanol mandates hit food producers hard. The Hill. 25 Jul. Available from: http://thehill.com/blogs/congress-blog/energy-a-environment/313241-no-doubtabout-it-ethanol-mandates-hit-food-producers-hard [Accessed 21 March 2014].

Butzen, S. and D. Haefele. 2008. Dry-grind ethanol production from corn. Available from: https://www.pioneer.com/home/site/ca/template.CONTENT/products/enduse/htf/guid.B6C03E1D-1585-429E-ABA8-104FB904EB63 [Accessed 21 March 2014].

Cameron, D. 2008. Agribusiness group forms to protect ethanol subsidies. Wall Street Journal, 25 Jul, Available from: http://online.wsj.com/article/SB121694492314783063.html [Accessed 31 Aug 2013].

Carney, D. 1995. Dwayne's world, Mother Jones, July/August. Available from: http://www.motherjones.com/politi cs/1995/07/dwaynes-world [Accessed 10 July 2013].

Carolan, M.S. 2009. A sociological look at biofuels: ethanol in the early decades of the twentieth century and lessons for today, Rural Sociology, 74(1), 86-112.

Cattle Buyers Weekly. 2013. Cattle Buyers Weekly. 23 Nov.

Center for Responsive Politics, 2013. Revolving door - Monsanto, Available from: http://www.opensecrets.org/revolvin g/index.php [Accessed 17 July 2013].

CGGC 2009. The hog farming value chain, Center for Globalization, Governance and Competitiveness, case study. Available from: http://www.soc.duke.edu/NC_GlobalEconomy/hog/value.shtml [Accessed 31 August 2013].

Clyma, K. 2011. On the verge: Smithfield is in the midst of changes that could result in record profits following years of record losses. Meat \& Poultry, 1 Jun. Available from: http://www.meatpoultry.com/articles/news_home/Business/2011/06/On_the_verge.aspx?ID=\%7 BC3BD844A-AF9F-4462-8540-34D5257BD78E\%7D\&p=1 [Accessed 21 March 2014].

Commodity Research Bureau 2010. CRB Commodity Year Book 2010. New Jersey: John Wiley \& Sons, Inc.

Corn for Food not Fuel (CFNF). 2014. Homepage. Available from: http://cornforfoodnotfuel.com/ [Accessed 20 June 2014\}.

Dauvergne, P. and K.J. Neville. 2009. The Changing North-South and South-South political economy of biofuels. Third World Quarterly, 30(6), 1087-1102.

Earth Policy Institute. 2014. Data Center. Available from: http://www.earthpolicy.org/?/data_center/C24/ [Accessed 20 June 2014].

Environmental Protection Agency. (EPA) 2013. AG 101: Major Crops Grown in the United States. Available from: http://www.epa.gov/oecaagct/ag101/cropmajor.html [Accessed 20 June 2014].

Falkner, R. 2009. The troubled birth of the "biotech century": global corporate power and its limits, in J. Clapp and D. Fuchs (eds), Corporate power in global agrifood governance (Cambridge, MA: Massachusetts Institute of Technology), pp. 225-52.

FAOSTAT 2014. Livestock primary data. FAO Statistics Division. Available from: http://faostat.fao.org/site/569/default.aspx\#ancor [Accessed 21 March 2014].

Fatka, J. 2011. DDGs: A feed market force. Farm Futures, Mar. Available from: http://magissues.farmprogress.com/FFU/FF03Mar11/ffu68.pdf [Accessed 21 March 2014].

Feedstuffs Magazine. 1968. Agricultural political power changing. Feedstuffs, 10 Aug, 20.

Fernandes, B.M., C.A. Welch and E.C. Gonçalves. 2010. Agrofuel policies in Brazil: paradigmatic and territorial disputes. The Journal of Peasant Studies, 37(4), 793-819.

Food Safety Magazine, 2007. Poultry breeder improves environmental monitoring with innovative dry-bags, Food Safety Magazine, Sep./Aug. Available from: 
http://www.foodsafetymagazine.com/magazine-archive1/augustseptember-2007/food-safetyinsider-solutions-in-rapid-microbiology/poultry-breeder-improves-environmental-monitoringwith-innovative-dry-bags/ [Accessed 31 August 2013].

Franco, J., L. Levidow, D. Fig, L. Goldfarb, M. Hö nicke and M.L. Mendonca. 2010. Assumptions in the European Union biofuels policy: frictions with experiences in Germany, Brazil and Mozambique. The Journal of Peasant Studies. 37(4), 661-98.

Friedmann, H. 1987. International regimes of food and agriculture since 1870. In: T. Shanin, ed. Peasants and peasant societies. Oxford: Basil Blackwell, pp. 258-76.

Friedmann, H. 2005. From colonialism to green capitalism: social movements and emergence of food regimes.In: F.H. Buttel. \& P. McMichael, eds. New directions in the sociology of global development: research in rural sociology and development, New York: Elsevier.

Friedmann, H. and P. McMichael. 1989. Agriculture and the state system: the rise and decline of national agricultures, 1870 to the present. Sociologia Ruralis, XXIX(2), 93-117.

Fuglie, K.O., P.W. Heisey, J.L King, C.E. Pray, K. Day-Rubinstein, D. Schimmelpfennig, S.L.Wang and R. Karmarkar-Deshmukh, 2011. Research investments and market structure in the food processing, agricultural input, and biofuel industries worldwide. US Department of Agriculture, Economic Research Service, report number 130, Dec. Available from: http://www.ers.usda.gov/publications/err-economic-research-report/err130.aspx\#.UiOGLzYqiSo [Accessed 31 August 2013].

Gillon, S. 2010. Fields of dreams: negotiating an ethanol agenda in the Midwest United States. The Journal of Peasant Studies, 37(4), 723-48.

Goodman, D., B. Sorj and J.Wilkinson, 1987. From farming to biotechnology: a theory of agroindustrial development (New York: Basil Blackwell).

Gottschalk, A. 2007. The Impacts of the U.S. corn/ethanol policy on the US cattle industry. Proceedings: The range beef cow symposium XX, 11-13 Dec., Fort Collins, Colorado. Available from: https://beef.unl.edu/beefreports/symp-2007-01-xx.shtml [Accessed 21 March 2014].

Heffernan, W. 1999. Consolidation in the food and agriculture system, report to the National Farmers Union. 5 February. Available from: http://www.foodcircles.missouri.edu/whstudy.pdf [Accessed 30 May 2012].

Henkoff, R. 1990. Oh, how the money grows at ADM. Fortune. 8 Oct. Available from: http://money.cnn.com/magazines/fortune/fortune_archive/1990/10/08/74164/ [Accessed 21 March 2014].

Hollander, G. 2010. Power is sweet: sugarcane in the global ethanol assemblage. The Journal of Peasant Studies, 37(4), 699-721.

Holleman, H. 2012. Energy policy and environmental possibilities: biofuels and key protagonists of ecological change. Rural Sociology,77(2), 280-307.

Hunsberger, C. 2010. The politics of jatropha-based biofuels in Kenya: convergence and divergence among NGOs, donors, government officials and farmers. The Journal of Peasant Studies, 37(4), 939-62.

Hunsberger, C. 2013. Jatropha as a biofuel crop and the economy of appearances: experiences from Kenya. Review of African Political Economy, DOI: 10.1080/03056244.2013.831753.

Index Mundi. 2014. Commodities. Available from http://www.indexmundi.com/commodities. \{Accessed 20 June 2014].

Julia and B. White. 2012. Gendered experiences of dispossession: oil palm expansion in a Dayak Hibun community in West Kalimantan. The Journal of Peasant Studies, 39:3-4, 995-1016.

Kaskey, J. 2010. DuPont gains on Monsanto as farmers question high-tech seeds. Bloomberg, 24 Aug. Available from: http://www.bloomberg.com/news/2010-08-24/dupont-gains-on-too-bigfor-britches-monsanto-as-farmers-switch-seeds.html [Accessed 1 September 2013].

Kilman, S., B. Ingersoll, and J. Abramson. 1995. Risk averse: how Dwayne Andreas rules ArcherDaniels by hedging his bets, CEO works with rivals, gives to both parties and invests in the media. Wall Street Journal, 27 Oct. 
Lagi, M., Y. Bar-Yam and K.Z. Bertrand, 2011. The food crises: a quantitative model of food prices including speculators and ethanol conversion. New England Complex Systems Institute, arXiv:1109.4859, September 21. Available from:http://necsi.edu/research/social/foodprices.html [Accessed 6 July 2013].

Langreth R. and M. Herper, 2009. The planet versus Monsanto. Forbes Magazine. Available from: http://www.forbes.co om/forbes/2010/0118/americas-best-company-10-gmos-dupont-planetversus-monsanto.html [accessed 17 July 2012].

Lehrer, N. 2010, US farm bills and policy reform: ideological conflict over world trade. Amherst: Cambria Press.

Manning, R. 2004. Against the grain: a portrait of industrial agriculture as a malign force. The American Scholar, 73(1), 13-35.

Mascarenhas, M. and Busch, L. 2006. Seeds of change: intellectual property rights, genetically modified soybeans and seed saving in the United States. Sociologia Ruralis, 46(2), 122-38.

McCarthy, J.F., P. Gillespie and Z. Zen. 2012. Swimming upstream: local Indonesian production networks in "globalized" palm oil Production. World Development, 40(3), 555-69.

McMichael, P. 2005. Global development and the corporate food regime. In: F.H. Buttel and P. McMichael, eds. New directions in the sociology of global development, Oxford: Elsevier, pp. 265-300

McMichael, P. 2009a. A food regime genealogy. The Journal of Peasant Studies. 36(1), 139-69.

McMichael, P. 2009b. The agrofuels project at large. Critical Sociology. 35(6): 825-39.

McMichael, P. 2009c. A food regime analysis of the 'world food crisis'. Agriculture and Human Values, (26), 281-95.

McMichael, P. 2010. Agrofuels in the food regime. The Journal of Peasant Studies, 37(4), 609-29.

McMichael, P. 2012. The land grab and corporate food regime restructuring. The Journal of Peasant Studies, 39(4), 681-701.

Meyer, P. 2005. Producers 'up to their eyeballs' in high fructose corn syrup. Milling \& Baking News, 31 May: 48.

Millet, G.T. 2006. Environmental science: working with the earth. California: Thomson Books.

Milling \& Baking News. 1982. EC subsidies impact ADM earnings. Milling \& Baking News. 12 Oct., 32.

Milling \& Baking News. 1984. Coca-Cola, PepsiCo authorize 100\% HFCS in soft drinks. Milling \& Baking News, 13 Nov., 11.

Milling \& Baking News. 2006. Controversy erupts between ADM and Cargill leaders over ethanol, Milling \& Baking News, 9 May., 11.

Mintz-Habib, N. 2013. Malaysian biofuels industry experience: a socio-political analysis of the commercial environment. Energy Policy, 56, 88-100.

Mitchell, D., 2008. A note on rising food prices. World Bank Report. Available from: http://wwwwds.worldbank.org/servlet/WDSContentServer/WDSP/IB/2008/07/28/00002043002/Rendered/P DF/WP4682.pdf [Accessed 6 July 2013].

Monsanto. 2003. Monsanto teams up with industry leaders to provide a major boost to ethanol and corn growers. Available from: http://news.monsanto.com/press-release/monsanto-teamsindustry-leaders-provide-major-boost-ethanol-and-corn-growers [Accessed 6 July 2013].

Montefrio , M.J.F. and D.A. Sonnenfeld. 2013. Global-local tensions in contract farming of biofuel crops involving indigenous communities in the Philippines, Society \& Natural Resources: An International Journal, 26:3, 239-253.

Mosley, B. 2008. Tyson CEO says ethanol will lead to higher food costs, Shelbyville TimesGazette, 27 Mar. Available from: http://www.t-g.com/story/1321018.html [Accessed 31 August 2013].

National Chicken Council (NCC). 2010. New members elected to National Chicken Council Executive committee and board of directors. Available from: http://www.nationalchickencouncil.org/new-members-elected-to-national-chicken-councilexecutive-committee-and-board-of-directors/ [Accessed 20 June 2014]. 
National Chicken Council (NCC). 2013. National Chicken Council's comments on the renewable fuel assessment white paper. 29 Apr. Available from: http://docs.house.gov/meetings/IF/IF03/20130723/101184/HHRG-113-IF03-20130723SD017.pdf [Accessed 31 August 2013].

National Turkey Federation. (NTF). 2014. Membership directory. Available from: http://www.eatturkey.com/content/membership-directory [Accessed 20 June 2014].

Nitzan, J. and S. Bichler, 2002. The global political economy of Israel. London: Pluto Press.

Nitzan, J. and S. Bichler, 2009. Capital as power: A study of order and creorder. Milton Park, Abingdon, Oxon: Routledge.

North American Meat Association. (NAMA). 2014. Member websites. Available from: http://meatassociation.com/about/member-websites [Accessed 23 June 2014].

Novo, A., K. Jansen, M. Slingerland and K. Giller. 2010. Biofuel, dairy production and beef in Brazil: competing claims on land use in São Paulo state. The Journal of Peasant Studies, 37(4), 76992.

Pollack, A. 2010. After growth, fortunes turn for Monsanto. New York Times. 4 Oct. Available from: http://www.nytimes.com/2010/10/05/business/05monsanto.html?_r=0 [Accessed 23 June 2014].

Pope, L. 2012. The ethanol mandate is worse than the drought. The Wall Street Journal, 27 Jul. Available from: http://online.wsj.com/article/SB10000872396390443343704577550831467098866.html [Accessed 31 August 2013].

Pork Checkoff, 2013. Quick facts: the pork industry at a glance, Iowa: National Pork Board. Available from: http://viewer.zmags.com/publication/5bb6aa6d\#/5bb6aa6d/1 [Accessed 31 August 2013].

Purdue Extension. 2013. Purdue Crop Cost \& Return Guide. Available from: http://www.agecon.purdue.edu/extension/pubs/id166_2013\%20_novembe.pdf [Accessed $31 \mathrm{Au}$ gust 2013].

Ray, D.E. 2009. Driven by ethanol at break-neck speed. Policy Pennings - Agricultural Policy Analysis Center, 12 June, Available from: http.//www.agpolicy.org/weekcol/463.html [Accessed 16 July 2013].

Ray, D.E. 2010. Farmers had a major role in jump-starting ethanol-based increases in corn demand, Policy pennings - agricultural policy analysis center, 12 Jun. Available from:http.//www.agpolicy.org/weekcol/542.html [Accessed 31 August 2013].

Renewable Fuels Association. (RFA). 2014. Members. http://www.ethanolrfa.org/pages/members [Accessed 20 June 2013\}.

Richardson, B. 2010. Big Sugar in southern Africa: rural development and the perverted potential of sugar/ethanol exports. The Journal of Peasant Studies, 37(4), 917-38.

Richardson, B. 2012. From a fossil-fuel to a biobased economy: the politics of industrial biotechnology. Environment and Planning C, 30(2), 282-96.

Rometsch, J. 2012. India's agrofuel policies from a feminist-environmentalist perspective. In: T. Potthast and S. Meisch eds. Climate change and sustainable development, The Netherlands: Wageningen Academic Publishers, pp, 233-8.

Shattuck, A. 2008. The agrofuels trojan horse: biotechnology and the corporate domination of agriculture, In: R. Jonasse ed. Agrofuels in the Americas. A Food First Book. Oakland: Institute for Food and Development Policy, pp. 89-101. Available from: http://www.foodfirst.org/files/pdf/Agrofuels_in_the_Americas.pdf [accessed 30 May 2012].

Southwestern Miller Magazine. 1972. ADM moves to broaden earnings base, The Southwestern Miller. 5 Sept. 17.

Tepe, F,S., D. Xiaodong and D.A. Hennessy, 2011. The impact of biofuels policy on agribusiness stock prices. Agribusiness. 27(2):179-92. 
UOIG. 2012. Deere \& Co. University of Oregon Investment Group. 30 May, Available from: http://uoinvestmentgroup.org/wp-content/uploads/2012/05/DEUpdate-Grace-Gong.pdf [Accessed 21 March 2014].

US Census Bureau. 2013. Concentration ratios. Available from: http://www.census.gov/econ/concentration.html [Accessed 6 July 2013].

US Department of Agriculture, Economic Research Service(USDA ERS) 1993. US corn sweetener statistical compendium, US Department of Agriculture, Stock \#94002.

US Department of Agriculture, Economic Research Service (USDA ERS). 2014a. Feed grains database. Available from: http://www.ers.usda.gov/data-products/feed-grainsdatabase.aspx\#.U6jPz_ldXfI [Accessed 20 June 2014].

US Department of Agriculture, Economic Research Service (USDA ERS). 2014b. Sugar and sweeteners yearbook tables. Available fom: http://www.ers.usda.gov/data-products/sugar-andsweeteners-yearbook-tables.aspx\#.U6jR0fldXfI [Accessed 20 June 2014].

US Department of Agriculture, Economic Research Service (USDA ERS). 2014c. Food availability (per capita) data system. Available from: http://www.ers.usda.gov/data-products/foodavailability-(per-capita)-data-system.aspx\#.U6jQ4fldXfI [Accessed 20 June 2014].

US Department of Agriculture, Economic Research Service (USDA ERS). 2014d. Corn supply, disappearance and share of total use. Available from: http://www.ers.usda.gov/datafiles/US_Bioenergy/Feedstocks/table05.xls [Accessed 20 June 2014].

US Department of Agriculture, National Agricultural Statistics Service (USDA NASS). 2013. Agricultural resource management survey. Available from: http://www.ers.usda.gov/dataproducts/arms-farm-financial-and-crop-production-practices.aspx [Accessed 20 June 2014].

US Energy Information Administration, (US EIA 2013). International energy statistics. Available from: http://www.eia.gov/cfapps/ipdbproject/IEDIndex3.cfm?tid=79\&pid=79\&aid=1 [Accessed 6 July 2013].

Vermeulen, S. and L. Cotula. 2010. Over the heads of local people: consultation, consent, and recompense in large-scale land deals for biofuels projects in Africa. The Journal of Peasant Studies, 37(4), 899-916.

Watt Poultry. 2014. Watt Poultry. Mar. Available from: http://www.wattpoultryusadigital.com/201403/Default/24/0\#\&pageSet=0 [Accessed 20 June 2014].

Weis, T. 2007. The global food economy: the battle for the future of farming. New York: Zed Books.

Weis, T. 2010. The accelerating biophysical contradictions of industrial capitalist agriculture. Journal of Agrarian Change, 10(3), 315-41.

White, B. and A. Dasgupta. 2010. Agrofuels capitalism: a view from political economy. The Journal of Peasant Studies, 37(4), 593-607.

Wilkinson, J. and S. Herrera. 2010. Biofuels in Brazil: debates and impacts. The Journal of Peasant Studies, 37(4), 749-68.

Winders, B. 2009. The politics of food supply: US agricultural policy in the world economy. Connecticut: Yale University Press.

Worldwatch Institute. 2014. Biofuel production declines. Available from: http://www.worldwatch.org/biofuel-production-declines-0 [accessed 20 June 2014].

Wright, B. 2014. Global biofuels: key to the puzzle of grain market behavior. Journal of Economic Perspectives, 28(1), 73-98.

Joseph Baines is a PhD candidate in the Department of Political Science at York University, Toronto. His research focuses on the global agricultural commodities traders and the restructuring of the world food system. He is also a registered volunteer at FoodShare Toronto. 